\title{
Street food vendors' entrepreneurial marketing characteristics and practices from 12 countries: what lessons can be learnt for improving food marketing in BOP/Subsistence marketplaces
}

\section{Martin Hilmi}

Governance Consultant, Food and Agriculture Organization of the United Nations (FAO), Viale delle Terme di Caracalla, Rome, Italy

$$
\text { Received: } 11 \text { March 2020/Accepted } 30 \text { April 2020 / Publication date: } 10 \text { May } 2020
$$

\begin{abstract}
The research was conducted to ascertain, assess and diagnose street food vendors' entrepreneurial marketing characteristics and practices in BOP/subsistence marketplaces and what lessons could be leant that may be of use to improve food marketing in BOP/subsistence marketplaces. The research was conducted via a qualitative abductive research method using secondary sources of data and information provided from case studies on street food vendors' marketing practices from 12 countries: Bangladesh, Botswana, Brazil, Cameroon, Ghana, India, Nepal, Niger, Republic of South Africa, Tanzania, Thailand, and Zimbabwe. The collected secondary data and information, was analyzed on the one side using content analysis and on the other side, using a more open approach, grounded theory. In the analysis seven entrepreneurial marketing characteristics out of the total 19 characteristics found were the same or related to a degree to street food vendors' marketing characteristics. In specific, in terms of street food vendors' entrepreneurial marketing characteristics, it was found that networks, knowledge of market demand, risk-taking, self-confidence (calculated risk-taking), low production costs (resource constrained), customer-relationships, and value creation were all an integral part of practice. It was found also that street food vendors' marketing characteristics were a 'mix' of entrepreneurial, micro, small and traditional marketing. The lessons learnt were, that for food marketing to be effective in BOP contexts, requires not simply knowing a market, but having a full understanding of the market (immersion), which for example attempts to understand not just the market, but the social ties and other aspects that may underline, for example, market demand. Immersion in such markets enables to build effective networks with, for example, social relations, word of mouth and social media. Further BOP contexts are risky and such risk can be mitigated via market immersion and networking so as to enable to take calculated risks and ensure risk is managed in appropriate ways. Costs must be kept low so as to be able to provide for low food prices, for example, in food marketing and customer relations are a vital necessity for food marketing in the BOP context. Such practices can support improved and more intensive food distribution and possibly support the reduction in malnourishment, hunger and starvation. Clearly there may be more lessons to be learnt for marketing food in BOP contexts that can contribute further to food marketing knowledge and also to marketing knowledge more in general. Thus further research is called for in this realm.
\end{abstract}

Keywords: Street food vendors, bottom of the pyramid, subsistence marketplaces, entrepreneurial marking, micro-enterprise marketing, food marketing

\section{Introduction}

\section{Background to the research}

Poverty is an endemic phenomenon that affects large parts of the world population: 'the number of poor worldwide remains unacceptably high, and it is increasingly clear that the benefits of economic growth have been shared unevenly across regions and countries' (World Bank, 2018, p.1). Poverty alleviation has attempted, for many decades now, to be tackled via, for example, foreign aid programs, microfinance, and property rights promotion, but more recently economic growth and its link to poverty reduction, via entrepreneurship, is also being considered. It is recognized that entrepreneurship may offer a significant part to the solution of poverty around the world ( $\mathrm{Si}$ et al.,

Corresponding Author: Martin Hilmi, Governance Consultant, Food and Agriculture Organization of the United Nations (FAO), Viale delle Terme di Caracalla, Rome, Italy.

E-mail: martin.hilmi@fao.org 
2019): the 'chronic nature of uncertainty provides a push to take action' (Viswanathan, 2016, p.29). Bridge et al., (2003) provide that entrepreneurship is associated with growth in an economy, but while there is 'considerable anecdotal evidence of successful ventures in poverty contexts, there is very little empirical support for the core proposition that businesses can profitably serve poor communities while helping to alleviate poverty'(Dembek et al., 2019, p.15). Hence the challenge, within the poverty domain, is 'to further understand entrepreneurship's link to poverty reduction and how productive entrepreneurship can be encouraged' (Si et al., 2019, p.2).

'Street vending or hawking is whereby people sell in or along streets' (Amoah-Mensah, 2016, p. 1651), and is a case in point as it is 'a vital piece of the economic framework of the poor who mostly belong to the deprived class of society' (Sarker et al., 2019, p. 1249). Street vending provides for employment and income generation for the poor as well as accessible and cheap services (Sarker et al., 2019). A particular type of street vending, that of food, be it unprocessed, semi-processed and prepared 'can be found on nearly every corner of the world and such foods have been on sale for thousands of years' (FAO, 2012, p.1). Further street food vending has provided for a 'growing form of employment, stability, and profitability, characterized by a high proportion of trade, most vendors being micro-entrepreneurs, and vendors' average incomes being generally higher than the official minimum wage and many vendors earn as much as school teachers or government clerks, but failure is also frequent' (Tinker, 1997, p. 149). Thus further research on street food entrepreneurship seems viable, as the past achievements of such micro-enterprises in terms of providing profitability, high income (revenue) generation and consequently stability (Tinker, 1997) for owners and their families, may seemingly derive from marketing practices. Hence a particular aspect of street food entrepreneurship will be considered in this research, that of entrepreneurial marketing (EM).

\section{Poverty: The bottom of the pyramid context}

There are circa four billion people who live in the BOP and currently, 736 million people, or 10.9 percent of the world population, live in extreme poverty, with an income of less than US\$1.9 per day, while 3 billion live on US $\$ 2.5$ per day and represent about 40 percent of the world population (World Bank, 2018, World Bank 2016). Thus about 50.9 percent of the world population live and work in BOP contexts.

Most of the people, living and working, in BOP contexts operate in what is called the informal economy. The informal economy covers all firms, workers and activities that operate outside the legal regulatory framework of society, and the output that they generate (WIEGO, 2012). Within this, the informal food economy relates to activities of food production, transport, and retailing, for example, that occur in informal settings and are not under the direct preview of national governments (FAO, 2003). It includes small producers, manufacturing enterprises, traders and service providers, involved in legal as well as unrecognized activities related to food (FAO, 2007). The informal food sector is mainly characterised by: low capital investments, absence of specialization, strong relationships between sellers and buyers, little accounts and taxes and permeability with the formal food sector (FAO, 2003). The BOP food sector alone represents about US\$3 trillion or 60 percent of all BOP consumer spending (Kacou, 2011).

Street food vendors are, in most cases, an integral part of the BOP informal food economy. FAO, (2012, p.2), defines street foods as 'ready-to-eat foods and beverages prepared and/or sold by vendors and hawkers especially in streets and other similar public places'. The foods are 'minimally processed to highly processed foods that are sold on streets and other public places, consumed on the spot and/or ready to take home or delivered to the work place, including catering' (FAO, 2012, p.2). Such foods are usually not expensive, are nutritional, are mostly based on traditional knowledge, tend to follow the seasonal pattern of farming, thus allowing for varied diets, and are widely distributed in both urban and rural areas (FAO, 2012). Street food enterprises are commonly family or one-person businesses (usually defined as micro enterprises), mostly run by women, and vendors can be mobile vendors, for example on foot and bicycles, semi-mobile, for example using push carts, or stationary vendors that sell from a stall (FAO, 2012). 
However, it is common thinking that such enterprises are not prone to business orientation, as the 'very poor are quite naturally risk averse, have to think short term to stay alive and often feel helpless to change their situation' ( Dalglish \& Tonelli, 2017, p. 6) along with the lack of literacy and numeracy skills, for example. But this is a fallacy as such sellers (and buyers) do function in the marketplace, provide mutually beneficial exchanges, teeming with ingenuity, and innovation that characterize such markets (Viswanathan \& Rosa, 2007). Marketplace exchanges play a central role for many poor consumers and entrepreneurs the world over ( Venugopal \& Viswanathan, 2017). The notion of enterprise for many is an abstraction as what they understand intuitively is exchange and are experts in survival (Viswanathan, 2016). It is estimated that about 'a billion entrepreneurs worldwide live in subsistence contexts and run micro-enterprises to meet life's basic consumption needs' (Venugopal et al, 2015, p.235). Such environments, although resource-poor with respect to income and literacy, are typically 'network-rich, with social ties among people that facilitate information sharing and the consequent development of consumer and entrepreneurial skills' (Viswanthan et al.,2010, p.570). Further many people are 'proactive, entrepreneurial innovators who are constantly co-creating solutions to survive the struggles of their daily lives and are a rich source of technological and business model innovations' (Fisk et al., 2016,p.45).

Street food enterprises have shown some signs of entrepreneurial and marketing orientation, as for example in Vietnam, street food enterprises, as reported by CNBC (2018), have provided to be very competitive in comparison to such multinationals as Burger King and McDonalds. In Vietnam, out of 540,000 food outlets, 430,000 are street food enterprises, and such enterprises can provide ready to eat food faster than both Burger King and McDonalds, offer more varied menus, at far lower prices, and provide food that is shareable with others, this providing well for Vietnamese social eating habits (CNBC, 2018). Further between 2016 and 2018 the international fast food chains operating in Vietnam saw a reduction of in-store customer traffic of 31 percent, while there was a 71 percent increase in customers eating street foods (CNBC, 2018). Mjoka et al., (2016) and Jongh (2015) also provide similar evidence on how competitive street food enterprises can be. Such competitiveness could be due to a number of entrepreneurial factors, including, but not limited to, for example management, finance, accounting, and marketing. However, it seems, from the above example of Vietnam that marketing as carried out by such entrepreneurs may be a key factor. Hence marketing as provided by entrepreneurs, EM, is of interest to this research, and in particular EM characteristics and practices of street food enterprises.

\section{The research aim}

The research aimed at exploring and attempting to ascertain, assess and diagnose street food vendors' $\mathrm{EM}$ characteristics and practices in $\mathrm{BOP} /$ subsistence marketplaces in defined case contexts and provide for lessons learnt that can be of use for improving food marketing in BOP/Subsistence marketplaces. Such increased knowledge in food marketing practices in BOP/Subsistence contexts, it is hoped, can support improved and more intensive food distribution and possibly support the reduction in malnourishment, hunger and starvation.

\section{Methodology ${ }^{1}$}

The research philosophies that provided the foundation of this research were positivism and interpretivism. Positivism 'entails working with an observable social reality to produce law-like generalizations' (Saunders et al., 2016, p. 135), while interpretivism provides that 'there is no single objective reality that can be observed: everything is open to subjective interpretation, with the possibility of multiple layers of meaning, therefore often less focused on testing theories and focuses on a more inductive process' (Rosen, 2019, p. 131). An abductive approach was taken: 'instead of moving from theory to data (as in deduction) or data to theory (as in induction), an abductive

1 The research was conducted over a six-month time period (September2019-Feburary 2020). The budget allocated for the research did not allow for field interviews in BOP/Subsistence marketplaces to be conducted. Consequently, the research was based on an extensive and in-depth literature review and on secondary sources of data and information. 
approach moves back and forth, in effect combining deduction and induction' (Saunders at al., 2016, p. 148). This provides for both considering the theoretical characteristics and practices of EM and the ground realities of EM characteristics and practices as provided by street food vendors. It enables to see from a 'top-down approach' and vice versa a 'bottom-up approach' of the realities on the ground. The abductive approach, hence, also enables for lessons learnt to be provided as theoretical characteristics and practices of EM and the ground realities of EM characteristics and practices as provided by street food vendors are combined. The research design was conducted via a qualitative abductive research method. Qualitative research is based on evidence from the real world: theories must be tested against the real world (Adams, 2014). Empirical, in this context, means its interpretive because it needs to make sense of the subjective and socially constructed meanings (Saunders et al., 2016). Qualitative research typically looks at a smaller number of cases more in depth, using data that cannot always be reduced to numbers, allows for richer description and can be better at identifying causal mechanisms (Rosen, 2019) rather than a generalization. The research is thus interpretive because there will be a need to make sense of the subjective and socially constructed meanings expressed about the phenomenon being studied (Saunders et al., 2016) and also inductive so as to possibly develop a richer theoretical (and practical) perspective that already exists in the literature (Saunders et al., 2016).

The nature of the research was exploratory and descriptive. It was exploratory so as to gain further insights about the research aim and objectives: the 'what' and 'how' of street food vendors' EM characteristics and practices. It was also descriptive so as to gain a better understanding of the profile of events, persons or situations: the 'Who', 'What', 'Where', 'When' or 'How', Saunders et al., (2016), of street food vendors' EM characteristics and practices.

The research was initially conducted by providing for a brief preliminary literature review to attempt to identify the main subject matter areas of concern i.e. to set the parameters. It was focused mainly on books and journal articles. The main areas identified where

- Marketing,

- Entrepreneurship,

- Entrepreneurial marketing

- Street food vendors' marketing

A second in-depth literature research and review was conducted. For each of the main subject matter areas, sub-subject matter areas were identified under each of the main headings as listed here below:

- Marketing

-Market orientation

-Customer orientation

-Small and medium enterprise marketing

-Small enterprise marketing

-Small business marketing

-Micro enterprise marketing

-Micro business marketing

-Food marketing

- Small and medium enterprise food marketing

-Small enterprise food marketing

-Small business food marketing

-Micro enterprise food marketing

-Micro business food marketing

- Entrepreneurship

-Entrepreneurial orientation

-Innovation orientation

-Creation logic

-Subsistence entrepreneurship 
-Transformational entrepreneurship

-BOP entrepreneurship

-Food entrepreneurship

-Street entrepreneurship

-Street food entrepreneurship

-Street food vendor entrepreneurship

- Entrepreneurial marketing

-Food entrepreneurial marketing

- Street food vendors' marketing

-Street food marketing

-Street food entrepreneurial marketing

-Street food vendors' entrepreneurial marketing

The literature research was conducted using five on-line databases: Google Scholar, EBSCOhost, JSTOR, Research gate and YouTube. The main key words used were those provided in the above list. These, however, were also combined using the 'Boolean' options: 'AND', 'OR' and 'NOT' options. For example, food AND marketing. The literature research followed the below quality criteria, in choosing pertinent publications, as adapted from Adams (2014), Saunders et al., (2016), Fisher (2011) and Jesson (2011):

- Provenance: Status and ranking of literature;

- Relevance: It is pertinent to the specific search research parameters used directly and indirectly;

- References: The type, relevance and provenance of the references provided;

- Soundness of arguments provided: Logical and critical argumentation provided from various recognized and objective sources and references provided;

- Contains research evidence used to support arguments: evidence and quality of factual information clearly presented;

- Provides both descriptive and analytical arguments;

- Peer reviewed: Reviewed by two or more reviewers;

- From a recognizable publisher/journal: The publisher/journal is recognizable as such

- Clear who is responsible for content: Author(s) are clearly stated and can be communicated with;

- Clear copyright indications.

The literature sought was mainly focused on journal articles and books with only some minor literature being, for example, on-line articles as well as videos. The above criteria were used as a 'checklist' to 'sift' through the literature and provide for inclusion of or exclusion of the literature. Of the 197 publications found, 134 of these passed the quality criteria checklist.

The secondary sources of data and information for the research were provided from case studies on street food vendors' marketing (SFVM) practices in BOP contexts from various countries in the world. The research was cross- sectional i.e. involving the study of a particular phenomenon at a particular time (Saunders et al., 2016) and the research was cross national, as per the call by Gilomore and Coviello (1999) to have more cross national studies of EM. The cases selected per BOP context (country) were based on a non-probability sample: purposive sampling or more specifically heterogeneous judgmental sampling. This was provided as per the lack of literature on the specific subject matter of the research, i.e. the research aim, the 'information richness' of such cases and the diverse and varied contexts each case provided for.

The search conducted for secondary sources of data and information, was conducted using five on-line databases: Google Scholar, EBSCOhost, JSTOR, Research Gate and YouTube. The specific parameters (key words) used were:

- Street food marketing

- Street food entrepreneurial marketing 
- Street food vendors' entrepreneurial marketing

These, however, were also combined using the 'Boolean' options: 'AND', 'OR' and 'NOT' options. For example, street AND Food AND marketing.

The secondary sources for data and information collection were selected and evaluated and based on the following criteria as adapted from Adams (2014), Saunders (2016), Fisher (2011) and Jesson (2011):

- Provenance: Status and ranking of literature;

- Relevance: It is pertinent to the specific search research parameters used directly and indirectly;

- Soundness of arguments provided: Logical and critical argumentation provided from various recognized and objective sources and reference provided;

- Case studies: An in-depth examination of a specific relevant case to the research questions;

- Contains empirical research evidence used to support arguments: evidence and quality of factual information clearly presented;

- Provides both descriptive and analytical arguments;

- Peer reviewed: Reviewed by two or more reviewers;

- From a recognized publisher/journal: The publisher/journal is recognizable as such.

The above criteria were used as a 'checklist' to 'sift' through secondary data and information and provide for inclusion of such data and information or exclusion in the research process. The total number of cases found were 47 , but as per the above listed selection criteria, 12 cases were selected. The selected cases derived from the following 12 countries: Bangladesh, Botswana, Brazil, Cameroon, Ghana, India, Nepal, Niger, Republic of South Africa, Tanzania, Thailand, and Zimbabwe.

The collected secondary data and information was analyzed on the one side using content analysis which is a "careful, detailed, systematic examination and interpretation of a particular body of material in an effort to identify patterns, themes, assumptions, and meanings' (Lune \& Berg, 2017, p. 182). In particular coding was used to convert the content into data, which was then analyzed. For example, the coding counted the frequency and context of the appearance of certain key words or phrases (Fisher, 2011) compared to the theoretical framework (see analysis secotion). For example, if the word innovation was found more than twice and this word being in the theoretical framework, this would be considered in the data and information collection be to relevant. On the other side, analysis was conducted via a more open approach, grounded theory, that provided for a process to 'analyze, interpret and explain the meanings that social actors construct to make sense of their everyday experiences in specific situations' (Saunders, 2016, p.193). For example, critical appraisals and conceptualization: critical appraisal provided for systematically assessing the evidence provided to verify the trustworthiness, value and relevance within the particular context and conceptualization in terms of the process used to provide meaning to the evidence and linking. Both of the chosen analytical methods fit in well with a qualitative abductive research method.

The quality of any qualitative research method risks bias as per the commonly subjective nature of such research processes. However, efforts were made to uphold the scientific method, and be as less bias as possible, following the criteria of validity, replicability, objectivity, falsifiability, and parsimony (Aston, 2019). Validity was upheld via the secondary data and information collection and how these were selected (see above criteria); replicability was enabled as other researchers can replicate the same findings via using the same research process proposed here; objectivity was upheld so as to reveal the true nature of the phenomenon under investigation without bias (as far as possible as per the qualitative nature of the research ); falsifiability was also considered as some of the theories and statements of EM could be provided to be false as a result of the current research; parsimony was applied as attempting to keeping explanations as simple and clear as possible (Aston, 2019). 


\section{Literature review}

The foundations of the research rested on entrepreneurship and marketing, and developed into exploring and investigating the interface between the two subject matters: EM. This was provided in a defined context, the BOP, within a specific industry, that of food, and considered in particular, a type of actor, street food vendors, and their enterprise size, micro -enterprise. Consequently, the literature review covered the subject matter areas of marketing, micro-enterprise marketing, entrepreneurship, EM, food marketing, food EM and SFVM.

\section{Marketing}

Kotler and Armstrong (2018, p.30), define marketing as 'the process enterprises engage customers, build strong relationships, and create customer value in order to capture value from customers in return'. The marketing process can be seen in Figure 1 below.

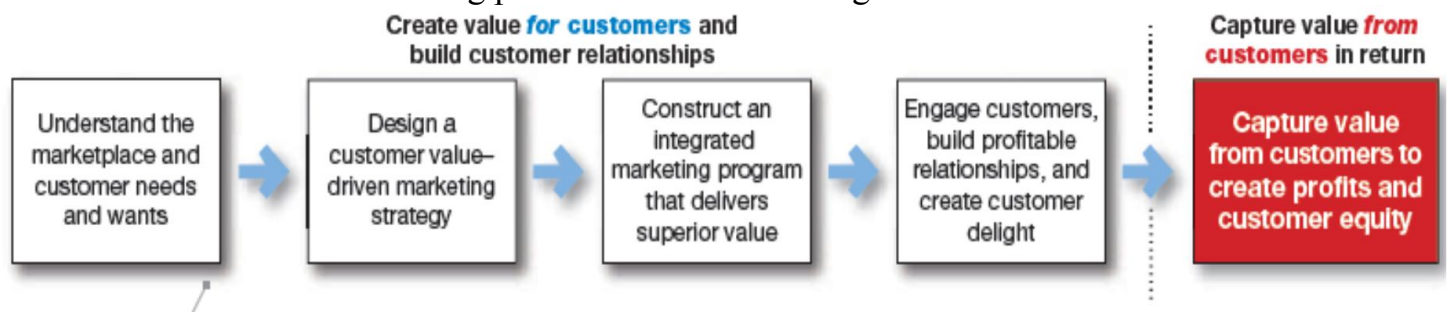

Fig. 1: The marketing process

(Source: Kotler \& Armstrong, 2018, p. 30)

The marketing process provides that achieving organizational goals depends on knowing the needs and wants of target markets and delivering the desired satisfactions better than competitors do (Kotler \& Armstrong, 2018). In Figure 1, enterprises in the step by step process, first seek to understand, gain knowledge, about consumers, then design a value based on this customer knowledge, provide the value, attempt to construct relationships with customers and hopefully at the end of the process reap the rewards of creating superior customer value (Kotler \& Armstrong, 2018).

Market-oriented businesses put the customer at the center stage, collect and disseminate intelligence about customers' current, latent and future needs, and on competition, and disseminate such intelligence within the business organization, and then take coordinated action to create superior customer value (Kohli \& Jaworski, 1990). Thus it is not only better understanding of customers that is important, but the sharing of this knowledge throughout the organization and translating this into customer value via coordinated marketing efforts. Market orientation is thus the implementation of marketing within organizations. The main characteristics of marketing can be seen in Table 1 .

Marketing is not just a functional process, but a philosophy of doing business which moves the producers' profit motive as its main objective to satisfying customers in the long run, which is likely to achieve the same financial reward and creates long-term customer equity (Baker \& Saren, 2010). In this, what is important is the producer's mindset: 'if this includes a concern for the customer's needs and wants, and appreciation of the benefits and satisfactions which are looked for, together with a genuine effort to establish a dialogue and build a long-term relationship, then this is the marketing philosophy irrespective of whether or not the organization possesses any personnel or function designated as marketing' (Baker \& Saren, 2010, p.24). Hence this provides that marketing is based on the 'mindset' of producers (entrepreneurs) as marketing in itself is a very creative and entrepreneurial activity, especially when operating in uncertain and competitive environments (Miles \& Arnold, 1991), but over the decades in attempts to formalize it, this has de-emphasized the more creative and entrepreneurial dimensions of it (Bjerke \& Hultman, 2002).

Marketing is a large and complex subject which covers a multitude of economic and social activities (Baker \& Saren, 2010). As provided, for example by Baker (2003) marketing ranges, for example, from economics (services marketing [ (see Palmer, 2003]), to psychology (relationship marketing [see O'Maley \& Tynan 2003]) to environmental (green marketing [see Peattie and Charter, 
2003]) to social (social marketing [see MacFadyen et al., 2003]) and cultural (international marketing [see Paliwoda, 2003]) aspects. Marketing also provides for size of the firm, for example, small enterprise marketing (see Carson, 2003) and per industrial sector, for example, food marketing (see FAO, 1997).

Table 1: Marketing characteristics

\begin{tabular}{lll}
\hline Exchanges & Communication & Value creation \\
Market -information centered & Promotion & Co-creation of value with customer \\
Market and customer segmentation & Strategic & Partnering \\
Markets and customers targeting & Planning & Networking \\
Customer centered & Integration & Natural environment sensitive \\
Customer satisfaction & Coordination & Societal sensitive \\
Customer relations & Innovative & \\
Employee relations & Experiential & \\
\hline
\end{tabular}

(Source: Kotler \& Armstrong, 2018)

\section{Micro-enterprise marketing}

There are many different definitions of what comprises a small enterprise: some use turnover, some employment and others use market share, for example (Bridge et al., 2003). 'Definitions also vary between countries depending on geographic location and the size and scope of the country's economy' ( Bloem, 2012, p. 2). Bloem (2012) researched over 19 countries in different continents and found in the majority of countries the number of employees is most often used to define small enterprises, this also being provided by Simpson et al., (2011). UNIDO \& OECD (2004, p.20) define a small enterprise based on employees and subdivides the 'small' into: 'self-employed; micro enterprise with 2 to 9 employees; and small enterprise with 10 to 49 employees'.

The majority of the literature, as provided here below, focuses on small enterprise marketing and not on micro-enterprise marketing. Street food vendors' enterprises are in the majority of cases micro-enterprises (FAO, 2012), however this does not exclude that marketing characteristics found in small enterprises may be similar and/or diverge from micro-enterprise marketing. This is so as the characteristics of small enterprises influence the marketing characteristics of such enterprises (Chaston et al., 1995). Chaston et al., (1995) provides that the level of marketing activity can be influenced by the age of the enterprise, the nature of the market, the marketing resources and marketing abilities available and consequently all effect marketing behavior. Carson et al., (1995) categorize the level of marketing activity in small enterprises: little or no marketing; implicit and simple marketing; and explicit and sophisticated marketing. Carson et al., (1995), Gilmore et al., (2001), Bjerke \& Hultman,( 2002), Chaston \& Mangles, (2002), Carson (2003), Simpson et al., (2011), Blankson et al., (2018,) and Gilmore \& Carson (2018,) find that micro and small enterprise marketing have the following characteristics as provided in Table 2 . Interestingly Table 2 below has some commonalties with Table 1 devoted to traditional marketing characteristics, for example such characteristics as innovation and relational focus appear in both tables.

Table 2: Micro and small enterprise marketing characteristics

\begin{tabular}{lll}
\hline Context specific & Networking & Innovative \\
Flexible & Relationships with customers & Risk-taking \\
Inherent informality in structure & Relationships with staff & Change-oriented \\
Restricted in scope and activity & Competitive alliances and support & Customer -focused relationships \\
Simple and haphazard & Intuitive & Morality \\
Product and price -oriented & Opportunistic & Religiosity \\
Owner/manager involvement & Adaptive & Resource constrained \\
\hline (Source: Based on: Carson et al., 1995; Gilmore et al., 2001; Bjerke \& Hultman, 2002; Chaston \& Mangles, \\
2002; Carson, 2003; Simpson et al., 2011; Blankson et al., 2018; Gilmore \& Carson, 2018)
\end{tabular}

Chaston \& Mangles (2002, p.12-13) find that small enterprises have four alternative and hybrid styles of marketing compared to traditional and standard marketing: 'transactional-conservative; 
relationship-conservative, transactional-entrepreneurial; and relationship - entrepreneurial'. But the existence of different approaches to marketing in small enterprises 'should not however, be interpreted that small enterprises reject classicist marketing thinking' (Chaston \& Mangles, 2002, p.17). Thus it may be provided that marketing in small enterprises has some of the basic dimensions of traditional and standard marketing, but others being very different (Bjerke \& Hultman, 2002). In small enterprises marketing implementation is more important to success than strategy and planning (Bjerke \& Hultman, 2002), and marketing is not a separate function from other business functions and has a special role in the success of small enterprises (Bjerke \& Hultman, 2002). Many small enterprises unconsciously do marketing and do not plan it (Cacciolatti \& Lee, 2015).

The majority of the literature, as provided previously, focuses on small enterprise marketing, but does not seemingly focus on micro-enterprise marketing specifically. In fact, Gherhes et al., (2016) find that micro enterprises are comparatively under researched, in general, while Blankson et al., (2018) call for more research to be conducted on micro-enterprise marketing in specific. Hence there is a lack of research conducted on the specific subject matter, as street food enterprises are commonly family or one-person businesses, defined as micro enterprises (FAO, 2012). Interestingly, however, there is seemingly no research on micro-enterprise EM and this 'research gap' provided for the research where street vendor micro-enterprise EM characteristics and practices are researched.

\section{Entrepreneurship}

Entrepreneurship, as defined by Barringer and Ireland (2016, p.10), is the 'process by which individuals pursue opportunities without regard to resources they currently control'. Much like marketing, entrepreneurship, can be seen as a process, a predicative logic, and includes all the functions, activities, and actions that are part of perceiving opportunities and creating organizations to pursue them (Bygrave \& Zacharakis, 2011). Table 3 shows the entrepreneurial process in a step by step manner.

Table 3: Entrepreneurship as a process

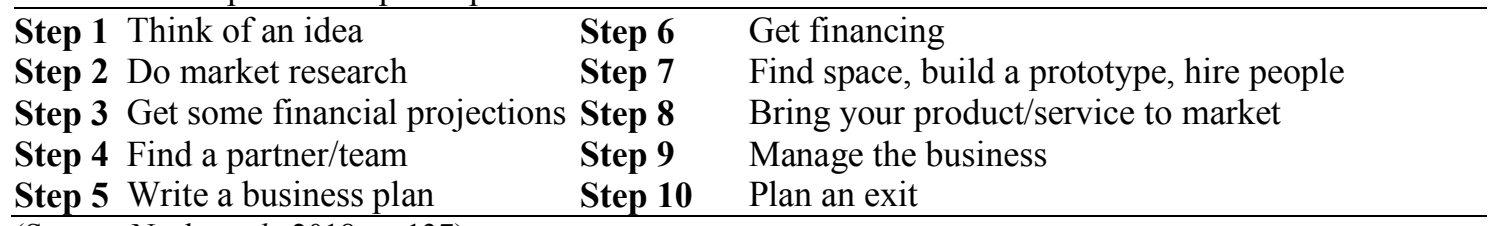
(Source: Neck et al., 2018, p. 137)

Neck et al., (2018) contend that the process (predicative) approach maybe viable in times of certainty and when there is access to existing information and data on which to base decisions, but the 'creation logic' is used when situations are more unpredictable and uncertain as provided by BOP contexts. The creation logic is 'an entrepreneurial mindset and a method that requires practice: it determines goals according to whatever resources that may be at hand' (Neck et al., 2018, p.116). In other words, entrepreneurship is a way of thinking and it needs to be 'done' with whatever resources may be available. This provides for patterns of how entrepreneurs think, act and relate to their social surroundings and within this there is what is termed effectuation: the future is unpredictable yet controllable (Neck et al., 2018). Entrepreneurs focus on creating their 'future rather than predicting it and this means they create new opportunities, make markets rather than find them, accept and learn from failure, and build relationships with a variety of stakeholders' (Neck et al., 2018, p.64). Commonly this type of entrepreneurship mindset and method starts as a practice, more than a process and starts small, with small actions and based on with what one has, considers acceptable losses as normal, embraces and leverages on failure, seeks for collaboration with other entrepreneurs and customers, experiments, is iterative and the future can be created and not predicted (Neck et al., 2018). In other words, this entrepreneurship mind and method navigates 'uncertain worlds to create rather than find existing opportunities, make markets, learns from failure, and connect with a variety of stakeholders to fulfill the vision of the future' (Neck et al., 2018, p.124). Thus entrepreneurship is 'certainly not linear or predictable; it is ill-defined, unstructured, and complex' (Neck et al., 2018, p. 137). 
In uncertain contexts, there are 'necessity-based entrepreneurs, those individuals who are pushed into starting a business because of circumstance, for example, lack of job availability and inability to find a job (Neck et al., 2018, p.94). Necessity -based entrepreneurship can also be referred to as subsistence entrepreneurship: located in 'settings of poverty in which a new venture offers little in terms of the potential to significantly improve the entrepreneur's life or that of the entrepreneur's family, engaging in entrepreneurial activities out of necessity' (Si et al., 2019, p. 8). There is also another type of entrepreneurship in such BOP contexts: 'opportunity-based entrepreneurs those who make a decision to start their own businesses based on their ability to create or exploit an opportunity' (Neck et al., 2018, p.94). These are referred to as transformational entrepreneurs and commonly are in far smaller numbers than subsistence entrepreneurs and 'strive for growth, are generally larger businesses, and provide relatively secure employment opportunities for others, are catalysts of innovation, job creation, productivity, and competitiveness' (Seja, 2013).

In terms of street entrepreneurship, Willams and Gurtoo (2012) define it as people selling on streets via temporary structures and/or mobile devices and in BOP contexts there can be street food enterprise that are family or one-person businesses (FAO, 2012) usually defined as micro enterprises, and as provided by Knox et al., (2019) 'survivalists' (subsistence/necessity entrepreneurs). But there can also be transformational entrepreneurs: 'street food vending that provided for upward mobility and turned them (street food vendors) into capitalists!' (ILO, 2006, p.13). This last point also being provided by Matzembacher et al., (2019) as street food entrepreneurs being transformational entrepreneurs. Thebe and Ncube (2015) find that there can be both, survivalists and transformational street food entrepreneurs.

Be it subsistence or transformational, entrepreneurship, like marketing, also interfaces with a number of disciplines ranging from psychology to economics, for example, and also includes such 'specialisms' as for example, entrepreneurship in small businesses (see Bridge et al., 2003), agricultural entrepreneurship (see Fitz-Koch et al., 2018) and also EM (see Bjerke \& Hultman, 2002). It is EM that was of interest for the research as an emanation of characteristics and practices from subsistence and transformational entrepreneurship of street food vendors.

\section{Entrepreneurial marketing}

The EM orientation refers to the 'interactions and actions of an enterprise pursuing new market opportunities in order to add value to the customer that may satisfy needs' (Sole, 2013, p. 29). In fact, the interface between marketing and entrepreneurial orientation, EM, are correlated (Miles \& Arnold, 1991), and further 'empirical evidence suggests that a positive and significant relationship exists between an enterprise's marketing and entrepreneurial orientation' (Morrish et al, 2010 p.308). A definition of EM provided by Cacciolatti \& Lee (2015, p. 4), encapsulate the interface: 'EM entails the proactive identification and exploitation of opportunities for acquiring and retaining profitable customers through innovative approaches to risk management, resource leveraging and value creation'. According to Collinson \& Shaw (2001) the interface between marketing and entrepreneurship share three main areas: change focused, innovative and opportunistic. This ties in well with the creative logic to entrepreneurship and as stated previously and provided by Bjerke \& Hultman, (2002), marketing in itself is a very creative and entrepreneurial activity, but over the decades in attempts to formalize it, this has de-emphasized the more creative and entrepreneurial dimensions of it.

But EM also has a customer and innovation orientation as these are inherent to both entrepreneurship and marketing (Jones \& Rowley, 2011). Customer orientation is the "culture that accentuates the creation of customer value as the overriding organizational goal (Jones and Rowley, 2011, p. 28), while innovation orientation is 'a set of understandings about innovation built into the fabric of an enterprise 's knowledge structure that influences organizational activities' (Siguaw et al., 2006, p.7). The four orientations of EM provide the basis for an EM theoretical framework as provided by Jones \& Rowley, (2011) and can be seen in Figure 2. Each orientation has a set of EM characteristics (Jones \& Rowley, 2011). 


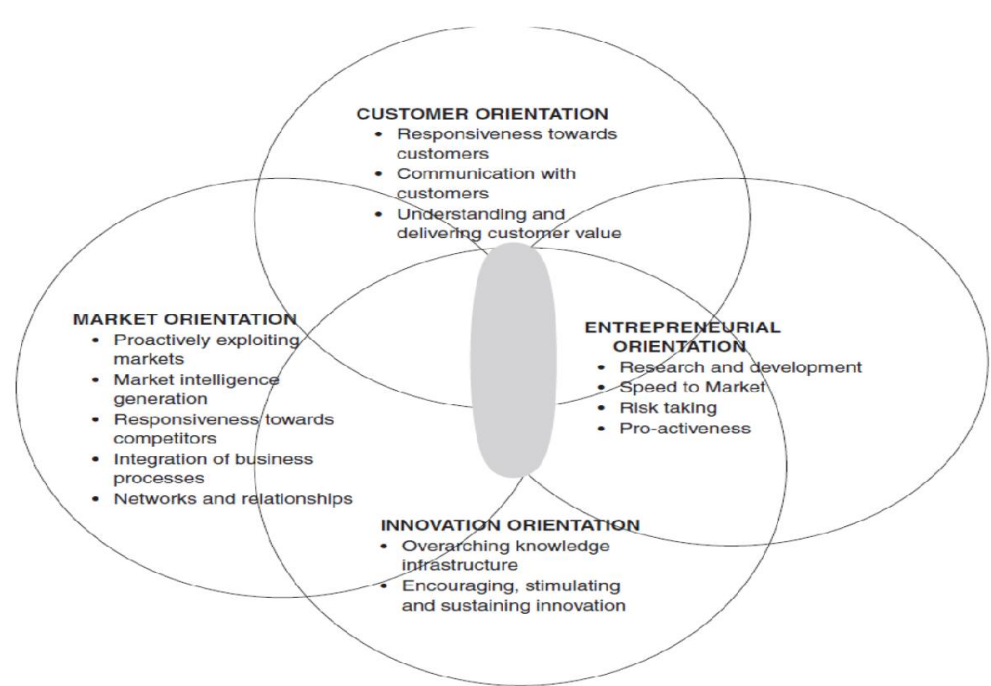

Fig. 2: The EM theoretical framework

(Source: Jones \& Rowley, 2011, p.31)

Consequently, as per Figure 2, 'the integration of these orientations (market, entrepreneurial, customer and innovation) are critical to the marketing-entrepreneurship interface and to the development of EM as a subject area' (Cacciolatti \& Lee, 2015, p.4). Collinson \& Shaw (2001) further provide that commonly EM is most apt for a fluctuating and changing environment and hence in line with the creative logic for both subsistence and transformational entrepreneurship as found in BOP contexts.

Miles et al., (2014, p.3) provide that there are three main schools of thought: "EM as entrepreneurship in marketing, (2) EM as networks and relationships in the context of SME marketing, and (3) EM as marketing in entrepreneurship'. Along the same lines, Hinson (2011), provides for much the same as entrepreneurship being in marketing and marketing being in entrepreneurship. But Morrish et al., (2010, p. 311) provide that 'EM is not simply the nexus of marketing and entrepreneurship, it is a synergistic opportunity-driven, innovation-oriented, proactive, risk-accepting set of processes for a marketer to gain competitive advantage'. Hence understanding EM 'is based on knowing how small enterprises actually do business and how they make decisions, deliver their market offering in the market place within the constraints of limited resources, expertise, impact and size' (Gilmore, 2011, p.138). EM 'is developed by the individual person, who will adapt traditional marketing frameworks to suit the specific situation of his/her own firm' (Gilmore, 2011, p.139). Carson et al., (1995) find four competencies for EM: knowledge and experience of the industry, product and marketing knowledge, communication skills and good capabilities in identifying market opportunities.

Moreover, Sadiko-Dushi and Ramadani (2019), provide that EM has its own distinct characteristics that differentiate it from 'traditional marketing' characteristics (see Table 1) based on four marketing principles (see Table 4). Commonly traditional marketing 'operates in a stable environment, where market conditions are continuous, while EM, operates in an uncertain environment, where market conditions are discontinuous and the needs of the market are as yet unclear' (Hills \& Hultman, 2013, p. 439).

From Table 4, EM is innovative and intuitive, bottom-up, interactive and informal in its networking and information gathering, while traditional marketing is market and customer driven, top-down, has formalized processes for researching markets and uses the marketing mix. Table 4, shows that there is a diversity between traditional marketing and EM. However, in the real world, as provided by Chaston (2000) not all small enterprises follow only EM, they may also follow more traditional marketing approaches, and hence their marketing may be seen as a 'mix'. 'This reflects very much entrepreneurial approaches to markets where there are strategic, sectoral, customer and performance conventions to follow. Some entrepreneurs will follow such conventions, others will 
break some of the conventions, while others will do both: a 'mix' ' (Chaston, 2000, p.14). In most small enterprises EM may be the prevalent style, but not always (Chaston \& Mangles, 2002) and 'for many small and entrepreneurial organizations EM has been long practiced by some and hence is second nature' (Collinson \& Shaw, 2001, p.763).

Table 4: Entrepreneurial marketing versus traditional marketing

\begin{tabular}{lll}
\hline Marketing principles & Traditional marketing & Entrepreneurial marketing \\
\hline Concept & $\begin{array}{l}\text { Customer-orientated: } \\
\text { Market-driven, product } \\
\text { development follows }\end{array}$ & $\begin{array}{l}\text { Innovation oriented: } \\
\text { Idea-driven, Intuitive assessment of } \\
\text { market needs }\end{array}$ \\
\hline Strategy & $\begin{array}{l}\text { Top-down segmentation, } \\
\text { targeting, and positioning }\end{array}$ & $\begin{array}{l}\text { Bottom-up targeting of customers and } \\
\text { other influence groups }\end{array}$ \\
\hline Tactics & The marketing mix, 4 Ps & $\begin{array}{l}\text { Interactive marketing methods } \\
\text { Word-of-mouth marketing }\end{array}$ \\
\hline Market intelligence & $\begin{array}{l}\text { Formalized research and } \\
\text { intelligence systems }\end{array}$ & $\begin{array}{l}\text { Informal networking and information } \\
\text { gathering }\end{array}$ \\
\hline
\end{tabular}

(Source: Sadiko-Dushi and Ramadani, 2019, p.11)

Consequently, in researching the characteristics of EM, considerations need to be taken for the size of the enterprise, the specific type of marketing being used based on the products/services being marketed, the industry-sector characteristics and norms, and the particular characteristics of the enterprise (Carson et al., 1995). In attempting to ascertain, assess and diagnose EM characteristics, literature was examined that covered the past four decades of EM research. The characteristics found are shown in Table 5.

Table 5: Characteristics of EM

\begin{tabular}{lll}
\hline Authors & Research Typology & Characteristics of EM \\
\hline $\begin{array}{l}\text { Sadiku-Dushi } \text { et } \text { al., } \\
(2019)\end{array}$ & $\begin{array}{l}\text { Literature \& } \\
\text { Empirical }\end{array}$ & $\begin{array}{l}\text { Proactive, growth oriented, risk taking, innovative, } \\
\text { opportunity oriented, resource leveraging, customer } \\
\text { intensity and value creation }\end{array}$ \\
\hline
\end{tabular}
Entrepreneurial, innovative, opportunity-driven,

Togharee et al., (2017) Literature calculated risk-taking, decisions based on intuition and of opportunities, flexible approaches to markets, exploitation of smaller market niches

\begin{tabular}{|c|c|c|}
\hline Shiratina (2016) & Literature & $\begin{array}{l}\text { Identification, exploitation, leveraging resources, } \\
\text { opportunity-driven, innovation, risk management, value } \\
\text { creation/creating value, create relationship and process }\end{array}$ \\
\hline Hills and Hultman (2013) & Literature & $\begin{array}{l}\text { Growth-oriented, opportunity-oriented, interactive, } \\
\text { market immersion, customer value }\end{array}$ \\
\hline Sole (2013) & Literature & Innovative, creative, proactive, risk-taking, \\
\hline Bettiol et al., (2012) & $\begin{array}{l}\text { Literature \& } \\
\text { Empirical }\end{array}$ & $\begin{array}{l}\text { Resource constraints, innovative, centrality of the } \\
\text { entrepreneur's decision making }\end{array}$ \\
\hline Gilmore (2011) & $\begin{array}{l}\text { Literature \& } \\
\text { Empirical }\end{array}$ & Networks, innovation, opportunistic, intuitive \\
\hline Morrish et al., (2010) & Literature & $\begin{array}{l}\text { Opportunity driven, innovation-oriented, proactive, risk } \\
\text { taking, customer centric, entrepreneur centric }\end{array}$ \\
\hline Kraus et al., (2010) & Literature & $\begin{array}{l}\text { Innovative, risky, opportunity-focused, proactive, } \\
\text { resource-constrained }\end{array}$ \\
\hline Hills et al., (2010) & Literature & $\begin{array}{l}\text { Customer centric, market immersion, networks, } \\
\text { relationships, }\end{array}$ \\
\hline Morris et al., (2002) & Literature & $\begin{array}{l}\text { Proactiveness, calculated risk-taking, innovativeness, } \\
\text { opportunity focus, dimension, resource leveraging, } \\
\text { customer intensity, value creation }\end{array}$ \\
\hline Collinson \& Shaw (2001), & Literature & $\begin{array}{l}\text { Change, innovative, responsive, opportunistic, adaptable, } \\
\text { creative, risk taking, networks, personality, intuition, } \\
\text { informality, quick decision making }\end{array}$ \\
\hline
\end{tabular}


The characteristics as per Table 5 above diverge and have similarities with traditional marketing characteristics as found in Table 1 and the same is valid for micro and small enterprise marketing characteristics as found in Table 2. However, this will be dealt more with in the analysis and findings section below.

In reviewing the EM literature, it provided for numerous research gaps. Miles et al., (2014) provide the need for simply more empirical research on EM, while Togharee et al., (2017) provide the need for more research in different contexts for EM. Hence the BOP context in this research accommodates for this. Morris et al., (2002) see more research needed on EM characteristics and this is reinforced by Hills and Hultman (2013) who call for establishing the distinctive characteristics of EM, which this research provides for. Nkamnebe \& Madichie, (1990) provide that more research is needed in small enterprise marketing in the informal economy. This call also is justified by this research, while Hills et al., (2008) and Hills and Hultman, (2013) point to more research in EM in both small firms and in all contexts, thus further justifying this research. Gross et al., (2014, p.117) provided further that 'researching marketing in SMEs and EM, at present, merely engages in discussions about '(entrepreneurial) marketing practices', without developing a genuine and deep understanding of it really and/or means in practice. Practices and questions about the nature of EM doings should be at the heart of current and future research interests'. This further seems to justify the research by looking at street food EM characteristics and practices. Lastly Sadikuo-Dushi et al., (2019), provide that it would be of interest to conduct research on EM in different industries. In this research the food industry, and in particular street food marketing is covered, and thus further seems to justify the research at hand.

\section{Food marketing and food entrepreneurial marketing}

Food marketing guides the production of food based on market demand as needed by customers (FAO, 1997,). Interestingly FAO (1997) considers the marketing philosophy and market orientation not only to be implemented within an organization but the entire food marketing system: 'the system comprises all of the functions, and agencies who perform activities, that are necessary in order to profitably exploit opportunities in the marketplace. Each of the components, or sub-systems, are independent of one another but a change in any one of them impacts on the others as well as upon the system as a whole' (FAO, 1997, p.19-20). The food marketing system is composed of four subsystems: production, distribution, consumption and regulatory.

Food marketing can be seen from a functional, institutional, behavioral and product point of view. Food marketing functions consider three types of functions: Exchange (buying and selling); physical (storage, transport, processing); facilitating (standardization, financing, risk bearing and market intelligence) (FAO,1997). Food marketing institutions are for example farmers, food processing enterprises and middle men traders and can be both private and public. There are also facilitative institutions, for example banks and transport firms and regulatory agencies concerned with food quality and labelling (Schaffner, 1998). Food marketing seen from a behavioral perspective considers the behaviors of the involved actors and institutions and why and how, for example, behavioral patterns may come about. Food marketing from a product point of view considers for example branded and commodity food products and how and why for example they are sold and bought.

Food marketing has been defined by FAO, (1997, p.21) as 'the series of services involved in moving a product (or commodity) from the point of production to the point of consumption', while Schaffner (1998, p.32) defines it as 'suppliers needing to identify the needs of buyers and tailor their marketing activities toward meeting these needs'. More recently, however, Hirst and Tressider (2016) see food marketing as more of an interaction and exchange of services. Food marketing is seen as 'a reorientation of the nature and roles of market actors and recasts value creation to a co-constitutive process between consumers, organizations and their stakeholders and where marketing facilitates this new value creation process and moves target customers to becoming active players and co-creators of personalized value' (Hirst \& Tressider, 2016, p.31). 
Moreover, food marketing, provides for experiential aspects that are commonly related to services and not commonly found in physical products such as food. Consequently, food marketing comprises not only the physical product, food, but also socio-cultural meaning experiences with the co-creation of this value also provided by consumers. In fact, in street foods marketing this seems to be the case: FAO (2012) provides that street foods provide for diverse cultural, ethnic and religious differences and further, Priviteri \& Nesci (2015), provide that such foods connect to the cultural, territorial, and ethnic backgrounds of a location and provide for communication and as an instrument of socialization and thus experiencing. Street foods are thus based on 'local knowledge and tradition and the highly competitive nature of street food markets, with many vendors in one location selling common dishes, provides opportunities for entrepreneurial skills to make product variations, which can provide advantage and favor among consumers' (FAO, 2012, p. 5).

In terms of food EM, Hill and Wright (2000) researched small and medium enterprises (SMEs) operating in the food sector and found that EM characteristics were dominated by a strong sales entrepreneurial orientation (personal selling), but also by experience, judgment, networks, intuition, communication and market knowledge. Kolabi et al., (2011) researched SMEs food EM and found that the owner/manager of the enterprise is central to EM. Fard and Amiri (2018) also researched SMEs food EM and found that processing, market knowledge and innovation were major characteristics. Olannye and Eromafuru (2016) researched fast food restaurants and found that opportunity recognition, proactiveness and innovation were all EM characteristics.

However, from the above, yet another two research gaps have emerged. There seems to be little previous research conducted on street food marketing not only as a physical product, but also as socio-cultural meaning experience with the co-creation of this value also provided by consumers. Further there seems to be no previous research conducted on food EM of street food vendors.

\section{Street food vendors' marketing}

In terms of street food vendors' marketing, ILO (2006) considers self-confidence, knowledge of market demand, networks, good relations with customers, good attire and appearance, food taste, price of food and selling location (ILO, 2006) all to be part of SFVM characteristics. Mjoka et al., (2016) report that SFVM is composed of offering lower prices, fresh food, differing and better foods, larger portions, and better service. Nirathorn (2005) finds that self-confidence, risk-taking, creativity, networks, location, taste and price, attire and behavior as well as the routes taken all are part of marketing activities. Pilz et al., (2016) find in terms of marketing that quality, hygiene and pricing were included in the marketing activities. Acho-chi (2002), Adhikari (2011), Carol et al., (2013), Edima et al., (2014) and FAO (2018) evidence the importance of location in terms of street food marketing. Otoo et al., (2011), Otoo et al., (2012) and Njaya (2014) also find location to be important, but add the importance of word of mouth to marketing activities. Thebe and Ncube (2015) found word of mouth also to be important in marketing, but social relations also to be important as also King (2016) found. Amoah-Mensah (2016) finds SFVM characteristics to be location, credit, flexible opening hours, low prices, sales promotions, changing products frequently and networking. Thatchinamoorthy \& Meenambigai (2017) find that in terms of SFVM low prices, quick service, variety of foods, quality, freshness and taste of food were all important characteristics, however the behavior of street food vendors and the report with clients was seen as most important. Matzembacher et al., (2019) provide that SFVM used social media. Khan (2017), provides that cheaper pricing, convenient location, shorter food delivery time, and lower production costs were all part of SFVM activities (Table 6 below provides a summary of SFVM characteristics). Khan, (2017) also points to further explore the boundaries and marketing capabilities of street food vendors.

Interestingly the SFVM characteristics seem to match in part the characteristics of traditional marketing (see Table 1) and those of micro and small enterprise marketing (see Table 2), as well as EM characteristics (see Table 5). These aspects will be dealt with further and more in-depth in analysis section devoted to the findings of the research. However, in all the literature reviewed on SFVM, 'traditional' marketing and not EM was considered. As shown in Table 4, the two types of 
marketing do differ and hence there is seemingly a "knowledge gap" in literature with regard to conducting research in street food vendors' EM.

Table 6: A summary of SFVM characteristics

\begin{tabular}{ll}
\hline Self-confidence & Lager portions \\
Risk-taking & Better service \\
Knowledge of market demand & Value creation \\
Social relations & Location \\
Relations with customers & Routes \\
Good attire and appearance & Word of mouth \\
Behavior of vendor & Flexible opening hours \\
Hygiene & Sales promotions \\
Low prices & Networking \\
Good tasting food & Social media \\
Fresh food & Short delivery time \\
Different foods offered & Low production costs \\
\hline
\end{tabular}

(Source: Based on: Acho-chi, 2002; ILO, 2006; Nirathron, 2005; Adhikari, 2011; Otoo et al., 2011; Otoo et al., 2012; Carol et al., 2013; Edima et al., 2014; Njaya, 2014; Thebe \& Ncube, 2015; Amoah-Mensah, 2016; King, 2016; Mjoka et al., 2016; Pilz et al., 2016; Khan, 2017; Thatchinamoorthy \& Meenambigai, 2017; FAO, 2018; Matzembacher et al., 2019)

\section{Analysis and findings}

\section{Theoretical framework}

The theoretical framework is based on the orientations and characteristics of EM. The EM characteristics, as found in Table 5, were compared with each other. If the same characteristic was found at least two times within what was identified by other authors, then the characteristic could be considered to be valid. This was provided so as to use more than one source of data and method of collection to confirm the validity/credibility/authenticity of the research data, analysis and interpretation (Saunders et al., 2016, P.207), as found in the characteristics in Table 5. The validated EM characteristics can be found in Table 7.

Table 7: Validated characteristics of EM

\begin{tabular}{ll}
\hline Proactive & Resource constrained \\
Growth-Oriented & Customer focused \\
Risk taking & Customer intensity \\
Calculated risk taking & Value creation \\
Risk management & Relationships \\
Innovative & Opportunity driven \\
Opportunity oriented & Market immersion \\
Opportunistic & Intuitive \\
Creative & Networks
\end{tabular}

Resource leveraging

(Source: Based on Collinson \& Shaw, 2001; Morris et al., 2002; Hills et al., 2010; Kraus et al., 2010; Morrish et al., 2010; Gilmore, 2011; Bettiol et al., 2012; Sole, 2013; Hills and Hultman, 2013; Shiratina , 2016; Togharee et al., 2017; Sadiku-Dushi et al., 2019)

As seen previously in the literature review, and in specific also in Figure 2, EM has four main orientations and these characteristics can be placed under each of these (see Table 8). This 'sorting' provides for greater clarity of the EM characteristics and where they 'fit' within the overall EM theoretical framework.

The characteristics found in Table 8 were used for analyzing the secondary sources of data and information collected from the 12 cases from 12 countries. Based on this, the collected data and information, were analyzed on the one side via content analysis (coding), for example, count the frequency and context of the appearance of certain key words or phrases (Collins, 2011) compared to 
the conceptual framework and on the other side a more open approach, grounded theory (critical appraisals, conceptualization, linking, etc.) as per the descriptive and explanatory nature of the research.

Table 8: Entrepreneurial marketing, its orientations and validated characteristics

\begin{tabular}{llll}
\hline $\begin{array}{l}\text { Market orientation } \\
\text { (MO) }\end{array}$ & $\begin{array}{l}\text { Entrepreneurial } \\
\text { orientation (EO) }\end{array}$ & $\begin{array}{l}\text { Customer } \\
\text { orientation (CO) }\end{array}$ & $\begin{array}{l}\text { Innovation } \\
\text { orientation (IO) }\end{array}$ \\
\hline Proactive & Risk taking & Customer focused & Innovative \\
\hline Market immersion & Calculated risk taking & Customer intensity & Creative \\
\hline Networks & Risk management & & Value creation \\
\hline Relationships & Opportunity-driven & & \\
\hline & Opportunistic & & \\
\hline & Intuitive & & \\
\hline & Resource-Leveraging & & \\
\hline & Resource constrained & & \\
\hline & Growth-oriented & & \\
\hline
\end{tabular}

(Source: Based on Collinson \& Shaw, 2001; Morris et al., 2002; Hills et al., 2010; Kraus et al., 2010; Morrish et al., 2010; Gilmore, 2011; Bettiol et al., 2012; Sole, 2013; Hills and Hultman, 2013; Shiratina , 2016; Togharee et al., 2017; Sadiku-Dushi et al., 2019)

\section{Analysis}

In analyzing the characteristics found in the theoretical framework, Table 8, with the characteristics of SFVM in Table 6 in the literature review, it was found that there are characteristics that are the same and some that are different (see Table 9).

Table 9: Similarities and differences between EM and SFVM characteristics

\begin{tabular}{|c|c|c|c|c|c|c|c|}
\hline MO & SFVMC-MO & EO & $\begin{array}{l}\text { SFVMC- } \\
\text { EO }\end{array}$ & $\mathrm{CO}$ & SFVMC-CO & IO & SFVMC-IO \\
\hline Proactive & & Risk taking & Risk taking & $\begin{array}{l}\text { Customer } \\
\text { focused }\end{array}$ & & Innovative & \\
\hline $\begin{array}{l}\text { Market } \\
\text { immersion }\end{array}$ & $\begin{array}{l}\text { Knowledge of } \\
\text { market demand }\end{array}$ & $\begin{array}{l}\text { Calculated } \\
\text { risk taking }\end{array}$ & $\begin{array}{l}\text { Self- } \\
\text { Confidence }\end{array}$ & $\begin{array}{l}\text { Customer } \\
\text { intensity }\end{array}$ & & Creative & \\
\hline \multirow[t]{10}{*}{ Networks } & Networking & $\begin{array}{l}\text { Risk } \\
\text { management }\end{array}$ & & Relationship & $\begin{array}{l}\text { Relations with } \\
\text { customers }\end{array}$ & $\begin{array}{l}\text { Value } \\
\text { creation }\end{array}$ & $\begin{array}{l}\text { Value } \\
\text { creation }\end{array}$ \\
\hline & Social relations & $\begin{array}{l}\text { Opportunity- } \\
\text { driven }\end{array}$ & & & $\begin{array}{l}\text { Behavior of } \\
\text { vendor }\end{array}$ & $\begin{array}{l}\text { Opportunity } \\
\text {-oriented }\end{array}$ & \\
\hline & Low prices & Opportunistic & & & $\begin{array}{l}\text { Good attire } \\
\text { and } \\
\text { appearance }\end{array}$ & & \\
\hline & Location & Intuitive & & & Hygiene & & \\
\hline & Routes & $\begin{array}{l}\text { Resource- } \\
\text { Leveraging }\end{array}$ & & & $\begin{array}{l}\text { Good tasting } \\
\text { food }\end{array}$ & & \\
\hline & Word of mouth & $\begin{array}{l}\text { Resource } \\
\text { constrained }\end{array}$ & $\begin{array}{l}\text { Low } \\
\text { production } \\
\text { costs }\end{array}$ & & Fresh food & & \\
\hline & $\begin{array}{l}\text { Flexible } \\
\text { opening hours }\end{array}$ & $\begin{array}{l}\text { Growth- } \\
\text { oriented }\end{array}$ & & & $\begin{array}{l}\text { Different food } \\
\text { offered }\end{array}$ & & \\
\hline & Sales promotion & & & & $\begin{array}{l}\text { Larger } \\
\text { portions }\end{array}$ & & \\
\hline & Social media & & & & Better service & & \\
\hline & & & & & $\begin{array}{l}\text { Short delivery } \\
\text { time }\end{array}$ & & \\
\hline
\end{tabular}

$(\mathrm{SFVMC}=\mathrm{SFVM}$ characteristic; $\mathrm{MO}=$ Market orientation; $\mathrm{EO}=$ Entrepreneurial orientation; $\mathrm{CO}=\mathrm{Customer}$ orientation; $\mathrm{IO}=$ Innovation orientation) 
The similarities and differences in Table 9 are discussed in the next section below.

\section{Findings and discussion}

\section{Market orientation}

SFVM is based on networks and to a degree on market immersion in terms of knowledge of market demand which is a component of it (see Table 9). These two characteristics are also EM characteristics. In terms of networking in SFVM characteristics, social relations and word of mouth are present and can be both an integral part of networking. However, in terms of EM characteristics social relations and word of mouth are not provided. Further all the other characteristics of SFVM seem to contribute to networking: social media, sales promotion, routes, location, low prices and flexible opening hours can all potentially contribute to this (see Table 9).

Interestingly though SFVM is not proactive. These findings seem to confirm that the context and type of entrepreneurship affects the kind of marketing, as provided previously, in the literature review. In BOP contexts there can be street food enterprise that are family or one-person businesses (FAO, 2012), usually defined as micro enterprises, and as provided by Knox et al., (2019) 'survivalists' (subsistence/necessity entrepreneurs), but also as reported by ILO (2006, p.13) transformational entrepreneurs: 'street food vending that provides for upward mobility and turned them (street food vendors) into capitalists!'. In fact, Thebe and Ncube (2015) find that there can be both, survivalists and transformational street food entrepreneurs. Typically, survivalists will to a greater degree use networks and knowledge of market demand in their marketing, while transformationals will use networks, market immersion and being proactive (Thebe \& Ncube, 2015).

The size of the enterprise also seems to affect EM, see Table 2, as micro and small enterprises market using networks and not being proactive. This yet again confirming that SFVM is in part EM and in part more traditional marketing. As provided previously in the literature review, small enterprises do not 'reject classicist marketing thinking' (Chaston \& Mangles, 2002, p.17) and that marketing in micro and small enterprises has some of the basic dimensions of traditional and standard marketing, but others being very different (Bjerke \& Hultman, 2002). Consequently, SFVM characteristics on the one side, seem to be a mix of EM, micro and small enterprise marketing and traditional marketing, networking and market immersion, with a strong focus on networking, but on the other side, not being proactive, and hence not being a mix of EM, micro and small enterprise marketing and traditional marketing.

This is an interesting finding as street food vendors' EM, relies on one side on being networked and in part market immersed, but on the other not being proactive as would more commonly be expected from such an entrepreneurial venture. This may point to the fact that some street food vendors are survivalists and thus rely on their networks to survive, with little need for their marketing to be proactive as they 'know their markets' and 'have their networks in place'.

Further in terms of market orientation, the findings provided that SFVM characteristics are only in part market-oriented, networking and market immersed, but are not proactive. Thus it may be inferred that street food enterprises are market -oriented to a medium degree based on EM characteristics, but are also to a lesser degree not -market oriented, still based on EM characteristics. It seems thus that this provides that in terms of marketing practice, street food vendors are only somewhat market-oriented in terms of EM.

\section{Entrepreneurial orientation}

From the analysis, SFVM is based on risk-taking, self-confidence (calculated risk-taking) and low production costs (resource constrained) which are all found also in EM characteristics (see Table 9). Self-confidence provides that the street food vendors have confidence in themselves and can take risks, but they are calculated risks and may also provide for risk management to a certain degree. Further it is interesting to note that the same characteristics, risk-taking and resource constrained (low production costs), also appear in Table 2 on micro and small enterprise marketing characteristics. 
This points to the fact, and supports much of what was found in the previous section on marketorientation, that SFVM is influenced by their context, BOP, that is risky and uncertain, are survivalists, the type of entrepreneurship, and the size of their enterprise, micro. Thus in marketing, street food vendors seem to face risk and hence take risk, but attempt to moderate the degree of risk via self-confidence (calculated risk-taking), market immersion and networks. However, it seems street food vendors even though take risk and take calculated risks (self-confidence) do not fully manage risk as per the EM characteristics. This though seems to be more a question of degree, as taking calculated risks is a component of risk management.

It is interesting to find that SFVM characteristics are not fully risk managed, and are not opportunity -driven, opportunistic, resource -leveraging, intuitive and growth oriented as provided by the EM characteristics. Yet again this may point to the fact of surviving, and thus not, for example being growth-oriented, risking resources on opportunities and being intuitive. However, for SFVM not being resource-leveraging is surprising. It would seem that in such dire contexts and enterprise size, resource leveraging, from an entrepreneurial -orientation, within marketing, would be provided on a constant basis. This could point yet again to the more survivalist type of entrepreneurship than its transformational typology in terms of its impact on marketing.

Further and also interestingly is that in Table 1, on traditional marketing characteristics, there is no mention of intuitive, opportunity -oriented and resource -leveraging characteristics, for example. This seems to stray away from the fact that, to some degree, marketing characteristics of micro and small enterprises as per Chaston \& Mangles, (2002) and Bjerke \& Hultman, (2002) have some of the basic dimensions of traditional and standard marketing. Moreover, Table 2, on characteristics of micro and small enterprise marketing, does provide for being intuitive and opportunistic but not opportunity -oriented and resource-leveraging, for example. This is interesting as it would seem that these last two characteristics of EM would be found within micro and small enterprise marketing, thus pointing to the fact that EM characteristics within the entrepreneurial orientation do vary, to some degree, to those of micro and small enterprise marketing characteristics. This portraying, to some degree, the uniqueness in EM characteristics.

Moreover, it is interesting to note that there seems to be in this particular case of SFVM, little entrepreneurial orientation as in the analysis only three of the EM characteristics were found to match out of the nine (see Table 9). This possibly pointing to the fact that SFVM does not have a high degree of entrepreneurial orientation in its practice, but focuses more on survival, stability and securing an income as provided previously by Tinker (1997).

\section{Customer Orientation}

From the analysis it was found that SFVM characteristic of customer relationship is to some degree in line with the same EM characteristic of relationships (see Table 9). Customer relationship is only one component of relationships, even though important, but relationships can be within networks, and include for example relations with suppliers, competitors, and so forth. However, customer relations also can be seen as part of this with the other two EM characteristics of customer focus and immersion. Further, other characteristics found of SFVM characteristics, seem all to support the EM characteristics. Out of the 10 characteristics identified all seem to support and be part of the EM characteristics. These are relations with customers, behavior of vendor, good attire and appearance, hygiene, good tasting food, fresh food, different foods offered, larger portions, better service and short delivery time. These characteristics seem to reinforce the EM characteristic of customer orientation. Hence SFVM does seem to have a high degree of customer orientation in its practice.

This high level of customer orientation is in line with the context, the BOP, the size of the enterprise and the type of entrepreneurship provided, being more survivalist, than transformational. The BOP context, as provided by Viswanthan et al., (2010, p.570), tends to be 'network-rich, with social ties among people'. The 'social ties' with people put a large accent on customer relationships as this may attempt to guarantee income and hence reduce income risk as well as reinforce networking. 
It also focuses on the fact that consumers in BOP contexts being income deficient, may only eat once per day, and hence they want to ensure that the meal they eat is not only nutritious but also tasty (Viswanathan, 2016). Further such a meal may also be bought on credit and hence both for the consumer and for the street food vendor a customer relation is important (Viswanathan, 2016).

Further such a characteristic of customer relationship is found also in traditional marketing, as per Table 1 and in micro and small enterprise marketing as found in Table 2. This seems, yet again to provide that marketing characteristics of micro and small enterprises as per Chaston \& Mangles, (2002) and Bjerke \& Hultman, (2002) have some of the basic dimensions of traditional marketing.

Interestingly there seems to be a logical reinforcing cycle sequence to the EM characteristics found in street food vendors' EM characteristics as networking and knowledge of market demand provides for social ties and put a large emphasis on customer relations, thus self-confidence in terms of calculated risk taking in marketing which in turn supports and reinforces networking. Thus SFVM has a medium degree of market orientation, a low degree of entrepreneurial orientation, and a high degree of customer orientation.

\section{Innovation orientation}

From Table 9 it can be seen that SFVM is not innovative, creative and opportunity-oriented in terms of the EM characteristic. Seeing the BOP context, the size of the enterprise and the type of entrepreneurship provided, being more survivalist than transformational, innovation means change and this may increase risks in an already risky and uncertain environment. FAO (2012) provides that street foods as products are mostly based on traditional knowledge and tend to follow the seasonal pattern of farming. Also Priviteri \& Nesci (2015), provide that such foods connect to the cultural, territorial, and ethnic backgrounds of a location. Thus being in line with local cultural and traditional eating habits and tastes, food products being offered may ensure sales and thus may provide for more probabilities of having assured income and thus reduce the degree of marketing risk.

The EM characteristic of value creation was found in SFVM characteristics (see Table 9). It is true that value creation can be innovative and creative to a degree, but in BOP contexts this may not be the case as per its dire nature. For example, a street food vendor providing for good tasting food, in larger portions and at low prices, all these characteristics found in SFVM characteristics, provide for value creation, but may not be considered to be innovative and creative. But this type of value creation can also be a way of being competitive, as provided by FAO (2012, p.5): 'with many vendors in one location selling common dishes, provides opportunities for entrepreneurial skills to make product variations, which can provide advantage and favor among consumers'. This interestingly pointing more towards transformational entrepreneurship than survivalist entrepreneurship. This providing for what Thebe and Ncube (2015) state that street food entrepreneurs can be both, survivalists and transformational.

Further innovation is a characteristic found in traditional marketing (see Table 1) and in micro and small enterprise marketing (see Table 2), but it seems not for street food vendors' EM characteristics to a greater degree. In terms of value creation, this characteristic is found in traditional marketing (see Table 1) and in EM characteristics of street food vendors, but not in micro and small enterprise marketing (see Table 2). This is interesting as on one side it provides for what Chaston \& Mangles, (2002) and Bjerke \& Hultman, (2002) provide in terms of some of the basic dimensions of traditional marketing are also found in micro and small enterprise marketing, but on the other side it does not.

Interestingly, it seems yet again, that there is a logical reinforcing cycle sequence to the EM characteristics found in street food vendors' EM characteristics. Networking and knowledge of market demand provides for social ties and put a large emphasis on customer relations, thus self-confidence in terms of calculated risk taking in marketing, which implies value creation, to retain customers and this in turn supports and reinforces networking and customer relations that reduces marketing risk. 
The innovation orientation within street food vendors' EM characteristics on one side seems to be innovation and creative averse to some degree, but far more value creation focused. Thus it may be inferred that street food enterprises are innovation -oriented to a lesser degree based on EM characteristics. It seems thus that this provides that in terms of marketing practice, SFVM is only somewhat innovation -oriented.

\section{Summary of the findings}

The orientations provided within EM showed that SFVM has a medium degree of marketorientation, have a low degree of entrepreneurial orientation, have a high degree of customer orientation, and a low degree of orientation towards innovation. In specific, in terms of street food vendors' EM characteristics, it was found that networks, knowledge of market demand, risk-taking, self-confidence (calculated risk-taking), low production costs (resource constrained), customerrelationships, and value creation were all an integral part of their practice. This represents seven EM characteristics out of the total 19 characteristics found in the EM theoretical framework that are the same or related to a degree. Table 10 provides for the seven EM characteristics of SFVM under each of the orientations.

Table 10: Street food vendors' EM characteristics

\begin{tabular}{llll}
\hline SFVMC-MO & SFVMC-EO & SFVMC-CO & SFVMC-IO \\
\hline $\begin{array}{l}\text { Knowledge of } \\
\text { demand }\end{array}$ & Risk taking & $\begin{array}{l}\text { Relations with } \\
\text { customers }\end{array}$ & Value creation \\
\cline { 1 - 3 } Networking & $\begin{array}{l}\text { Self-Confidence (Calculated risk } \\
\text { taking ) }\end{array}$ & \\
\hline & $\begin{array}{l}\text { Low production costs (resource } \\
\text { constrained) }\end{array}$ & \\
\hline
\end{tabular}

$(\mathrm{SFVMC}=\mathrm{SFVM}$ characteristic; $\mathrm{MO}=$ Market orientation; $\mathrm{EO}=$ Entrepreneurial orientation; $\mathrm{CO}=\mathrm{Customer}$ orientation; $\mathrm{IO}=$ Innovation orientation).

Interestingly each of the seven characteristics contributed to another in a logical reinforcing cycle sequence as networking and knowledge of market demand provides for social ties and put a large emphasis on customer relations, thus self-confidence in terms of calculated risk taking in marketing, which implies value creation, to retain customers and this in turn supports and reinforces networking and customer relations that reduces marketing risk. This logical reinforcing cycle sequence of EM characteristics being influenced by the context, the BOP, which is risky and uncertain, the size of the enterprise, micro, and the typology of entrepreneurship, tending in degree more to survivalist than to transformational. It was also found that street food vendors' EM characteristics were in part also based on traditional marketing characteristics and those of micro and small enterprise marketing characteristics. But also there were divergences, pointing possibly to the fact that EM characteristics are unique.

\section{Conclusions}

In terms of ascertaining, assessing and diagnosing street food vendors' EM characteristics and practices in BOP food markets, the research in 12 countries found seven out of the 19 EM characteristics to be either the same or related to a good degree. This provides to be nearly about 40 percent of SFVM provides for EM characteristics. However other characteristics of SFVM, indirectly, feed into the other EM characteristics, and seemingly support them. For example, in networking, SFVM characteristics of social relations and word of mouth, do support networking. Hence seemingly there is a convergence of SFVM characteristics into EM characteristics. But SFVM characteristics also have traditional marketing and micro and small enterprise marketing characteristics. These seem also, in part to overlap with EM characteristics. Thus it can be said that SFVM characteristics from this research are a 'mix' of EM, micro and small as well as traditional marketing.

Further, in specific, the EM characteristics of SFVM are interestingly set in a logical reinforcing cycle sequence as knowledge of market demand and networking provides for social ties and puts a large emphasis on customer relations, thus self-confidence in terms of calculated risk taking in 
marketing, which implies value creation, to retain customers and this in turn supports and reinforces networking and customer relations that reduces marketing risk. This seems to fit in and is logical in the BOP settings which are risky and uncertain, the typology of entrepreneurship that is more survivalist than transformational and hence risk averse for example, and the type of enterprise, micro, which commonly has few resources to spare, for example, and thus needs to take calculated risks. Thus it seems that these characteristics are set in a strategic marketing manner so as to tender for more effective marketing in BOP contexts.

This is further reinforced by the SFVM EM orientations that provided for a medium degree of market-orientation, a low degree of entrepreneurial orientation, a high degree of customer orientation, and a low degree of orientation towards innovation. This, yet again, shows that in BOP settings, marketing needs a high degree of customer orientation, providing customer value, a fair degree of market orientation, where markets are known, focusing mainly on customers, but the more entrepreneurial and innovative orientation to marketing is moderated by the inherent risks found commonly in BOP contexts.

Consequently, the lessons learnt from the characteristics and practices of street food vendors' EM and how these may be of use to food marketing in such BOP contexts are as follows:

- Market immersion: Marketing in BOP contexts seems to require market immersion, thus knowing market demand, but not only, for example, being knowledgeable of the social ties, the good locations and routes to market food products, to who and when to provide sales promotions, what opening hours to keep and so forth, are also required. This is a first lesson learnt as market immersion within BOP contexts seems to be a 'must' for food marketing. Hence marketing food requires not simply knowing a market, but having a full understanding of the market (immersion), which for example understands not just market demand, but the social ties and aspects behind that may underline the market demand, for example. Market immersion seemingly is an integral part of marketing in BOP settings and thus needs to be implemented to provide for more effective food marketing and thus contribute to improved food distribution and reduction, for example, in malnutrition;

- Networking: Networking in dire contexts enables to market food products in a defined way and is based also on market immersion (knowledge of market demand). Thus the second lesson learnt for food marketing in BOP contexts is that there is a need to be immersed in such markets, so as to be able to build effective networks with, for example, social relations, word of mouth and social media. These will all contribute to more effective marketing implementation in BOP contexts;

- Risk-Taking: This looks at the inherent and high risk of marketing food in BOP contexts. Street food vendors, however, as per the BOP context, their nature of survivalists and size of enterprise, micro, cannot take excessive risks in marketing and seem to moderate this risk taking for example via market immersion and networks which tend to reduce marketing risk. This is the third lesson learnt for food marketing in BOP contexts: food marketing is risky in BOP contexts and needs to be considered, hence this risk needs to be mitigated via market immersion and networking in marketing implementation;

- Self-confidence: A part of self-confidence is taking calculated risks and risk management. This in terms of food marketing in such a dire context of the BOP seems to be natural as a wrong marketing decision could lead to business failure of a street food vendor as, for example, the resource constraints of such businesses. This provides that food marketing in such context needs to cater for risk and manage it as per the volatile nature of BOP. This seemingly is done via market immersion and networking. The fourth lesson for food marketing in BOP contexts is thus to take calculated risks and ensure risk is managed in appropriate ways, as per the previous lessons of market immersion and networking;

- Low production costs: This is part of the EM characteristic of being resource constrained as low production costs are not only a reality of such resource constrained street food enterprises, but also a necessity so as to keep low selling prices. Hence food marketing in such BOP contexts seems to deem low production costs so as to provide for low prices that 
BOP consumers can afford. This is the fifth lesson learnt for food marketing in BOP contexts: costs must be kept low so as to be able to provide for low food prices, for example;

- Relations with customers: This aspect for SFVM is paramount as customers provide income to the business and hence there is a focus and intensity with customers. This provides that in BOP contexts food marketing needs to have a very strong emphasis on customer relationships. This provides for the sixth lesson in food marketing: customer relations are a vital necessity for food marketing in the BOP context. This marketing relational aspect ties in with knowing the customer (market immersion), networking (social ties, etc.,), reducing risks (calculated risk taking), and low costs. The customer relational focus in BOP contexts is seeing the customers as not just a primary asset, but also for example, seeing the customer in social terms;

- Value creation: Leading on from the previous EM characteristics value must be provided to customers. Such value may not necessarily have to be innovative and/or creative, but must have value in customer terms. This is the seventh lesson learnt in terms of food marketing in BOP contexts: customer value is important and must not be necessarily innovative and /or creative, but must be valued primarily by the customer, on customer terms. Such knowledge can be understood via market immersion, networking and fostering customer relations, for example.

The seven main lessons learnt for food marketing in the BOP can be adopted and implemented by private, non-profit, and public organizations marketing food in such contexts. Improved and better food marketing in BOP contexts, as has been found, has important elements of EM, but also micro and small enterprise marketing as well as traditional marketing. These practices can support improved and more intensive food distribution and possibly support the reduction in malnourishment, hunger and starvation.

\section{Further research}

From this research there are some areas that emerge that require further investigation. Undoubtedly more research needs to be conducted on the EM characteristics found in this research so as to investigate further and ascertain and better understand such marketing characteristics and practices and how these can further enable and enhance food marketing in BOP contexts. For example, a more specific and in-depth research on market immersion and networking in BOP contexts could help and support better food marketing in such contexts. Research could also be provided on EM by street food vendors' marketing, but in other countries than the ones provided from this research and possibility not just using secondary sources of data and information, but also based on primary field data and information. Research could also be conducted further on how the BOP context affects the marketing of micro enterprises of street food vendors. Further, research could be conducted also, in specific, in micro-enterprise street food EM so as to possibility ascertain if in fact street food marketing provided by survivalist (micro) enterprises may be distinctive or not from more transformational (small) street food enterprise marketing. Moreover, further research could be conducted on why street food enterprises have such low degrees of entrepreneurial and innovation orientation in EM.

\section{References}

Acheampong, G., and M. Esposito, 2014. The nature of entrepreneurship in bottom of the pyramid markets', Int. J. Entrepreneurship and Small Business, 21(4): 437-456.

Acho-Chi, C., 2002. The mobile street food service practice in the urban economy of Kumba, Cameroon, Singapore Journal of Tropical Geography, 23(2):131-148.

Adams, J., H.T.A. Khan, and R. Raeside, 2014. Research Methods for Business and Social Science Students, $2^{\text {nd }}$ edition, Sage, Los Angeles, CA, USA

Adhikari, D. B., 2011. Income generation in the informal sector: A case study of street vendors in Kathmandu metropolitan city, Economic Journal of Development Issues, 13and 14 (1-2):1-14.

Amoah-Mensah, A.2016. Street Vending and Competitive Advantage: Towards Building a Theoretical Framework, The Qualitative Report, 21(9): 1651-1673 
Aston. 2019. On-line lessons, Section 3 research methods, Research methodologies overview, [online] available

https://vle.aston.ac.uk/webapps/blackboard/execute/displayLearningUnit?course id= 226671 \&content $\mathrm{id}=1474154 \_$(Accessed 1/10/2019)

Baker, M.J., (Ed). 2003. The marketing book, $5^{\text {th }}$ edition, Butterworth Heinemann, Oxford, UK

Baker, M.J., and Saren, M(Eds). 2010. Marketing theory: A student text, $2^{\text {nd }}$ edition, Sage, London

Banjaree, A. V., and E. Duflo, 2011. Poor Economics: A Radical Rethinking of the Way to Fight Global Poverty, Public affairs, New York, NJ, USA

Barringer, B.R., and R. D. Ireland, 2016. Entrepreneurship: Successfully launching new ventures, Pearson

Berg, B.L., and H. Lune, 2017. Qualitative research methods for social sciences, $9^{\text {th }}$ edition, Pearson, Harlow, UK

Bettiol, M., E. Di Maria, and V. Finotto, 2012. Marketing in SMEs: the role of entrepreneurial sensemaking, Int. Entrep. Manag. J., 8:223-248

Bjerke, B., and Hultman, C.M. 2002. Entrepreneurial marketing: The growth of small firms in the new economic era, Edward Elgar, Cheltenham, UK

Blankson, C., K. Cowan, and W. K. Darley, 2018. Marketing Practices of Rural Micro and Small Businesses in Ghana: The Role of Public Policy, Journal of Macromarketing, 38(1): 29-56.

Bloem, J., 2012. Micro, small and medium enterprise definitions, Partners worldwide

Bridge, S., K. O'Neill, and S. Cromie, 2003. Understanding enterprise, entrepreneurship and small business, $2^{\text {nd }}$ edition, MacMillan, London

Bygrave, W., and W. Zacharakis, 2011. Entrepreneurship, $2^{\text {nd }}$ edition, Wiley. Hoboken, NJ, USA

Cacciolatti, L., and S. H. Lee, 2015. Entrepreneurial marketing for SMEs, Palgrave MacMillan, London

Cardoso, R.C.V., M. Companion, and S.R. Marras, (Eds).2014. Street Food: Culture, economy, health and governance, Routledge, Oxon, UK.

Carol, N., C. Matenge, and H. Ongori, 2013. An Assessment of Challenges faced by Microenterprises in Botswana: A case of Street Food Vendors in Gaborone, International Journal of Learningand Development, 3(5): 56-73

Carson, D., 2003. Marketing for small to medium enterprises, In Baker,M.J. (Ed). 2003. The marketing book, $5^{\text {th }}$ edition, Butterworth Heinemann, Oxford, UK

Carson, D., S. Cromie, P. McGowan, and J. Hill, 1995. Marketing and entrepreneurship in SMEs: An innovative approach, Prentice Hall, London

Carson, D. and S. Cromie, 1989. Marketing planning in small enterprises: A model and some empirical evidence, Journal of Marketing Management, 5(1): 33-49.

Chachine, T., 2016. Introduction to social entrepreneurship, CRC press, Boca Raton, FL, USA

Chambwera, M., J. MacGregor, and A. Baker, 2011. The informal economy, iied

Chaston, I., 2000. Entrepreneurial marketing: Competing by challenging convention, MacMillan press, London

Chaston, I., and T. Mangles, 2002. Small business marketing management, Palgrave, Houndmills, UK

Chen, M.A., 2016. The Informal Economy: Recent Trends, Future Directions, NEW SOLUTIONS: A Journal of Environmental and Occupational Health Policy, 1-18.

CNBC.2018. Why McDonalds flopped in Vietnam, Available at https://www.youtube.com/watch?v=19pthhpd7So ( Accessed 22/11/2019)

Collinson, E., and E. Shaw, 2001. Entrepreneurial marketing - a historical perspective on development and practice, Management Decision, 39(9): 761 - 766.

Dalglish, C., and M. Tonelli, 2017. Entrepreneurship at the bottom of the pyramid, Routledge, London

Dembek, K., N. Sivasubramaniam, and D.A. Chmielewski, 2019. A Systematic Review of the Bottom/Base of the Pyramid Literature: Cumulative Evidence and Future Directions, Journal of Business Ethics, 1-18.

Duus, H.K., 1997. Economic foundations for an entrepreneurial marketing concept, Scand. J. Mgmt., 13(3): 287-305. 
Edima, H.C., R.K. Tem Nnam, T. Awono Enama, D.M. Biloa, and R. Ndjouenkeu, 2014. Case Study of the Street Food Sector in the Metropolitan Areas of a Cameroonian City, Yaounde, International Journal of Current Microbiology and Applied Sciences, 3 (9): 740-751.

Eggers, F., G.E. Hills, and G. Omura, (eds). 2014. Research and the marketing/ entrepreneurship interface, Global Research Symposium on Marketing and Entrepreneurship

Fard, M. H., and N.S. Amiri, 2018. The effect of entrepreneurial marketing on halal food SMEs performance, Journal of Islamic Marketing, 9 (3): 598-620.

Fisher, C.2011. Researching and writing a dissertation: An essential guide for business students, $3^{\text {rd }}$ edition, Pearson, Harlow, UK.

Fisk, R.P., L. Anderson, D.E. Bowen, T. Gruber, A. Ostrom, L. Patricio, J. Reynoso, and R. Sebastiani, 2016. Billions of impoverished people deserve to be better served: A call to action for the service research community, Journal of Service Management, 27(1): 43-55.

Fitz-Koch, S., M. Nordqvist, S. Carter, and E. Hunter, 2018. Entrepreneurship in the Agricultural Sector: A Literature Review and Future Research Opportunities, Entrepreneurship Theory and Practice, 42(1):129-166.

Food and Agriculture Organization (FAO).2018. Street food in Tanzania: A literature review, Rome

FAO.2012. Selling street and snack foods, Rome .

FAO.2007. Promises and challenges of the informal food sector in developing countries, Rome.

FAO.2005. Changes in food retailing in Asia, Rome.

FAO.2003. The informal food sector, Rome.

FAO.1997. Agricultural and food marketing management, Rome.

Gherhes, C.A., N. Williams, T. Vorley, et al. (1 more author) (2016) Distinguishing micro-businesses from SMEs: a systematic review of growth constraints, Journal of Small Business and Enterprise Development, 23 (4): 939-963

Gilmore, A. 2011. Entrepreneurial and SME marketing, Journal of Research in Marketing and Entrepreneurship, 13(2): 137-145.

Gilmore, A. and D. Carson, 2018. SME marketing: efficiency in practice, Small Enterprise Research, 25(3): 213-226.

Gilmore, A., D. Carson, and K. Grant, 2001. SME marketing in practice, Marketing Intelligenceand Planning, 19(1): 6-11.

Gilmore, A., and N. Coviello, 1999. Methodologies for research at the marketing/entrepreneurship Interface, Journal of Research in Marketing and Entrepreneurship, 1(1): 41 - 53.

GIZ. 2012. Green Urban Economy: Conceptual Basis and Courses of Action, Eschborn, Germany

Gross, N., D. Carson, and R. Jones , 2014. Beyond rhetoric: re-thinking entrepreneurial marketing from a practice perspective, Journal of Research in Marketing and Entrepreneurship, 16(2): $105-127$

Hill, J., and L.T. Wright, 2000. Defining the scope of entrepreneurial marketing: A qualitative approach, Journal of Enterprising Culture, 8 (1) 23-46.

Hills, G.E., and C. Hultman, 2013. Entrepreneurial Marketing: Conceptual and Empirical Research Opportunities, ERJ, 3(4): 437-448.

Hills, G.E., C. Hultman, S. Kraus, and R. Schulte, 2010. History, theory and evidence of entrepreneurial marketing - an overview, Int. J. Entrepreneurship and Innovation Management, 11(1): 3-18.

Hills, G.E., C. Hultman, and M.P. Miles, 2008. The Evolution and Development of Entrepreneurial Marketing, Journal of Small Business Management, 46(1): 99-112.

Hinson, R., 2011. Entrepreneurship marketing, In NwanKwo, S., and Gbadamosi, A. 2011. Entrepreneurship marketing: Principles and practices of SME marketing, Routledge, London

Hirst, C., and R. Tressider, 2016. Marketing in tourism, hospitality, events and food: A critical approach, $2^{\text {nd }}$ edition, Goodfellow Publishers Limited, Oxford, UK.

Hisrich, R.D., M.P. Peters, and D.A. Shepherd, 2017. Entrepreneurship , $10^{\text {th }}$ edition, McGraw Hill, New York, NY, USA

Huq, I., and B.A. Mallik, 2009. Entrepreneurs of the Streets: an Analytical Work on the Street Food Vendors of Dhaka City, International Journal of Business and Management, 4(2): 80-88

International Labor Organization (ILO).2006. Fighting poverty from the street: A survey of street food vendors in Bangkok, Geneva 
Jaworski, B., and A. Kohli, 1993. Market orientation: antecedents and consequences. Journal of Marketing, 57(3):53-70.

Jesson, J.K., L. Matheson, and F.M. Lacey, 2011. Doing Your Literature Review traditional and systematic techniques, Sage, Los Angeles, CA, USA

Jones, R., M. Suoranta, and J. Rowley, 2013. Entrepreneurial marketing: a comparative study, The Service Industries Journal, 33 (7-8): 705-719.

Jones, Rand J. Rowly, 2011. Entrepreneurial marketing in small businesses: A conceptual exploration, International Small Business Journal, 29(1):25-36.

Jong, L. 2015. Street Vending in Urban Malawi: Strategies and Practices of Vendors and Local Authorities,

Paper, RC21 International Conference "The Ideal City: between myth and reality. Representations, policies, contradictions and challenges for tomorrow's urban life" Urbino, Italy, 27-29 August 2015

Kacou, E., 2011. Entrepreneurial Solutions for Prosperity in BoP Markets: Strategies for Business and

Economic Transformation, Pearson Education, Upper Saddle River, NJ, USA

Khan, E. A. 2017. An investigation of marketing capabilities of informal microenterprises: A study of street food vending in Thailand, International Journal of Sociology and Social Policy, 37(3/4):186-202.

King, A. 2016. Access to Opportunity: A Case Study of Street Food Vendors in Ghana's Urban Informal Economy, In Gender and Food: From Production to Consumption and After Advances in Gender Research, 22: 65-86

Kohli, A., and B. Jaworski, 1990. Market orientation: the construct, research propositions, and managerial

implications. Journal of Marketing, 54 (2):1-18.

Kolabi, A.M., H.K. Hosseini, R.Mehrabi, and A. Salamzadeh, 2011. Developing Entrepreneurial Marketing Mix: Case Study of Entrepreneurial Food Enterprises in Iran, Journal of Knowledge Management, Economics and Information Technology

Kolk, A., M. Rivera-Santos, and C. Rufin, 2014. Reviewing a Decade of Research on the "Base/Bottom of the Pyramid" (BOP) Concept, Businessand Society, 53(3):338-377.

Kotler, P., and G. Armstrong, 2018. Principles of marketing, $17^{\text {th }}$ edition, Pearson, Harlow, UK

Kotler, P., N. Roberto, and T. Leisner, 2006. Alleviating poverty: A macro/micro marketing perspective, Journal of Macromarketing, 26:233-239.

Knox, A. J., H. Bressers, N. Mohlakoana, and J. De Groot, 2019. Aspirations to grow: when microand

informal enterprises in the street food sector speak for themselves, Journal of Global Entrepreneurship Research

Kraus, S., R. Harms, and M. Fink. 2010. Entrepreneurial marketing: Moving beyond marketing in new ventures, Int. J. Entrepreneurship and Innovation Management

Legge, J., and K. Hindle, 2004. Entrepreneurship: Context, vision and planning, Palgrave MacMillan, New York, NJ, USA.

Lodish, L.M., H.L. Morgan, and A. Kallianpur, 2001. Entrepreneurial marketing: Lessons from Wharton's Pioneering MBA Course, Wiley, New York, USA

Lune, H., and B.L. Berg, 2017. Qualitative research methods for social sciences, $9^{\text {th }}$ edition, Pearson, Harlow, UK.

Lynn MacFadyen, L., M. Stead, and G. Hastings, 2003. Social marketing, In Baker,M.J. (Ed). 2003. The marketing book, $5^{\text {th }}$ edition, Butterworth Heinemann, Oxford, UK

Maclaran, P., M. Saren, B. Stern, and M. Tadajewski, (Eds).2010. The Sage handbook of marketing theory, London.

Matzembacher, D. E., R.L. Gonzales, and C.S.V. Saldanha, 2019. Can street entrepreneurs be Schumpeterian

entrepreneurs? The case of food trucks as family firms in an emerging country, Journal of Global Entrepreneurship Research, 9(6):1-24.

Miles, M., A. Gilmore, P. Harrigan, G. Lewis, and Z. Sethna, 2014. Exploring entrepreneurial marketing, Journal of Strategic Marketing 
Miles, M., and D. Arnold, 1991. The Relationship Between Marketing Orientation and Entrepreneurial

Orientation, Entrepreneurship theoryand practice

Mjoka, J., M. Selepe, and C. du Preez, 2016. An investigation into business practices of selected street food vendors at KwaDlangezwa, Northern KwaZulu Natal, African Journal of Hospitality, Tourism and Leisure, 5 (2).

Morris, M.H., M. Schindehutte, and R.W. LaForge, 2002. Entrepreneurial marketing: A construct for integrating emerging entrepreneurship and marketing perspectives, Journal of Marketing Theory and Practice, 10(4) 1-19.

Morrish, S. C., 2011. Entrepreneurial marketing: a strategy for the twenty-first century? Journal of Research in Marketing and Entrepreneurship, 13(2):110 - 119.

Morrish, S.C., M.P. Miles, and J.H. Deacon, 2010. Entrepreneurial marketing: acknowledging the entrepreneur and customer-centric interrelationship, Journal of Strategic Marketing, 18:4, pp. 303-316

Neck, H. M., C.P. Neck, and E.L. Murray, 2018. Entrepreneurship: The practice and mindset, Sage, Los Angeles, USA.

Nirathron, N., 2006. Fighting Poverty from the Street: A Survey of Street Food Vendors in Bangkok, International Labour Office, Bangkok

Nirathron, N. 2005. The Business of Food Street Vendors in Bangkok: An Analysis of Economic Performance and Success, Canadian Journal of Development Studies / Revue canadienne d'études du développement, 26(3): 429-441.

Njaya, T. 2014. Nature, Operations and Socio-Economic Features of Street Food Entrepreneurs of Harare, Zimbabwe, Journal Of Humanities And Social Science, 19(4): 49-58.

Nkamnebe, A. D., and N.O. Madichie, 2010. Entrepreneurial marketing in informal economies,

Olannye, A.Pand E. Eromafuru 2016. The Dimension of Entrepreneurial Marketing on the Performance of Fast Food Restaurants in Asaba, Delta State, Nigeria, Journal of Emerging Trends in Economics and Management Sciences, 7(3):137-146.

O’Malley, L., and C. Tynan, 2003. Relationship marketing, In Baker,M.J. (Ed). 2003. The marketing book, $5^{\text {th }}$ edition, Butterworth Heinemann, Oxford, UK

Otoo, M., G. Ibroo, J. Fultonand J. Lowenberg-Deboer, 2012. Micro-Entrepreneurship in Niger: Factors Affecting the Success of Women Street Food Vendors, Journal of African Business, 13(1):16-28.

Otoo, M., G. Ibroo, J. Fultonand J. Lowenberg-Deboer, 2011. Women Entrepreneurship in West Africa: The Cowpea Street Food Sector in Niger and Ghana, Journal of Developmental Entrepreneurship

Paliwoda, S.J., 2003. International marketing: the issues, In Baker,M.J. (Ed). 2003. The marketing book, $5^{\text {th }}$ edition, Butterworth Heinemann, Oxford, UK

Palmer, A., 2003. The marketing of services, In Baker,M.J. (Ed). 2003. The marketing book, $5^{\text {th }}$ edition, Butterworth Heinemann, Oxford, UK

Pansera, M., and R. Owen, 2014. Collaboration for Sustainability and Innovation: A Role for Sustainability Driven by the Global South? A Cross-Border, Multi-Stakeholder Perspective, Springer, The Netherlands

Peattie, K., and M. Charter, 2003. Green marketing, In Baker,M.J. (Ed). 2003. The marketing book, $5^{\text {th }}$ edition, Butterworth Heinemann, Oxford, UK

Pilz, M., G. Uma, and R. Venkatram, 2014. Skills development in the informal sector in India: The case of street food vendors, Int Rev Educ

Prahalad, D., 2019. The new fortune at the bottom of the pyramid, Consumerand Retail, [online] available athttps://www.strategy-business.com/article/The-New-Fortune-at-the-Bottom-of-thePyramid (accessed 18/09/2019)

Prahalad, C.K., 2005. The fortune at the bottom of the pyramid, Pearson education, Upper Saddle River, NJ, USA

Presutti, M., and V. Odorici, 2018. Linking entrepreneurial and market orientation to the SME's performance growth: the moderating role of entrepreneurial experience and networks, International Entrepreneurship Management Journal, 
Privitera, D., and F. Nesci, 2015. Globalization vs. local. The role of street food in the urban food system, Procedia Economics and Finance, 22: 716 - 722.

Ratten, V., P. Jones, V. Braga, and C.S. Marques, 2019. Subsistence Entrepreneurship: The interplay of collaborative innovation, sustainability and social goals, Springer, Cham, Switzerland

Rosen, A.M., 2019. Effective research methods for any project, The teaching company, Chantilly, VA, USA

Sadiku-Dushia, N., L. Danab, and V. Ramadania, 2019. Entrepreneurial marketing dimensions and SMEs performance, Journal of Business Research, 100: 86-99.

Sadikuo-Dushi, N., and V. Ramadani, 2019. Entrepreneurial marketing: What we know and what we should know? conference paper, 3rd International Scientific Conference on Business and Economics

Sarker, N.I., Z. Rahman, Q. Cao, and Z. Xu, 2019. Impact of small entrepreneurship on poverty alleviation and sustainable livelihood of street vendors, International Journal of Innovation and Applied Studies, 25 (4): 1241-1254.

Saunders, M., P. Lewis, and A. Thornhill, 2016. Research methods for business students, $7^{\text {th }}$ edition, Pearson, Harlow, UK

Schaffner, D.J., W.R Schroder, and M.D. Earle, 1998. Food marketing: An international perspective, Mc Graw-Hill, Boston, MA, USA

Seja, M. 2013. Placing your bets: Subsistence or Transformational Entrepreneurship, [on-line] available athttps://blogs.worldbank.org/psd/placing-your-bets-subsistence-or-transformationalentrepreneurship (accessed 27/11/2019)

Sharp, B., 2013. Marketing: Theory, evidence, practice, Oxford University Press, Victoria, Australia

Shiratina, A. 2016. The chronology of entrepreneurial marketing definitions, $I J$ A B E R, 14(1).

Si, S., D. Ahlstrom, J. Wei, and J. Cullen, 2019. Business, entrepreneurship and innovation toward poverty reduction, Entrepreneurshipand Regional Development,

Siguaw, J. A., P. M. Simpson, and C. A. Enz, 2006. Conceptualizing innovation orientation: A framework for study and integration of innovation research, [on-line] available at http://scholarship.sha.cornell.edu/cgi/viewcontent.cgi?article=1855\&context=articles (accessed 09/12/2019)

Simpson, M., N. Taylor, and J. Padmore, 2011. Marketing in SMEs, In NwanKwo, S., and Gbadamosi, A. 2011. Entrepreneurship marketing: Principles and practices of SME marketing, Routledge, London

Singapore Statement of Research Integrity. 2010. The principles, 2nd World Conference on Research Integrity, 21-24 July 2010, [on-line] available at https:/www.jsps.go.jp/english/ekousei/data/singapore_statement_EN.pdf (Accessed 1/10/2019)

Skinner, C. 2016. Informal Food Retail in Africa: A Review of Evidence, Consuming Urban Poverty Project

Working Paper No. 2, African Centre for Cities, University of Cape Town, Cape Town, South Africa

Sole, M. 2013. Entrepreneurial marketing: conceptual exploration and link to performance, Journal of Research in Marketing and Entrepreneurship, 15(1): 23-38.

Stokes, D. 2000. Entrepreneurial marketing: a conceptualization from qualitative research, Qualitative Market Research: An International Journal, 3 (1): 47 - 54.

Thatchinamoorthy, C., and J. Meenambigai, 2017. Customer Relationship Management and Retention in Street Food Sector, Food and Nutrition Journal, 1-5.

Thebe, Pand G. Ncube, 2015. Street entrepreneurship in Zimbabwe: Survivalist or growth oriented? A case of Bulawayo city centre, International Journal of Development and Sustainability, 4(2): 126-144.

Tinker, I.,1997. Street foods: Urban food and employment in developing countries, Oxford University press, Oxford, UK

Toghraee, M.T., M. Rezvani, M.H. Mobaraki, and J.Y. Farsi, 2017. A Systematic Review on Entrepreneurial Marketing: Three Decade Research on Entrepreneurial Marketing, International Journal of Applied Business and Economic Research, 15(8) 273- 296.

UNIDOand OECD. 2004. Effective policies for small business, Paris

Venugopal, S., 2016. Entrepreneurial marketing in subsistence marketplaces, $\mathrm{PhD}$ thesis, 
University of Illinois at Urbana-Champaign, [on-line] available at https://www.ideals.illinois.edu/bitstream/handle/2142/90919/VENUGOPAL-DISSERTATION2016.pdf?sequence $=1$ (accessed 09/12/2019)

Venugopal, S., and M. Viswanathan. 2017. The subsistence marketplaces approach to poverty: Implications for marketing theory, Marketing Theory, 1-16

Venugopal, S., M. Viswanathan, and K. Jung, 2015. Consumption Constraints and Entrepreneurial Intentions in Subsistence Marketplaces, Journal of Public Policyand Marketing, 34(2):235-51.

Viswanathan. M., 2016. Bottom-Up Enterprise: Insights From Subsistence Marketplaces,

Viswanathan. M., 2013. Subsistence Marketplaces,

Viswanathan. M., R. Echambadi, S.Venugopal, and S. Sridharan, 2014. Subsistence entrepreneurship, value creation, and community exchange systems: a social capital explanation, Journal of Marco marketing, (34):1-14.

Viswanathan. M., S. Sridharan, and R. Ritchie, 2010. Understanding consumption and entrepreneurship in subsistence marketplaces, Journal of business research, 63: 570-581.

Viswanathan, M., and J.A. Rosa, 2007. Product and Market Development for Subsistence Marketplaces, Advances in International Management, 20: 1-17.

WIEGO.2012. The informal economy: definitions, theories and policies, Manchester, UK

Williams, C.C., and A. Gurtoo, 2012. Evaluating competing theories of street entrepreneurship: some lessons from a study of street vendors in Bangalore, India, Int. Entrep. Manag. J., 8: 391-409

World Bank. 2018. Poverty and shared prosperity 2018: Piecing together the poverty puzzle, Washington D.C.

World Bank, 2016. Poverty and Shared Prosperity 2016: Talking on inequality, Washington D.C

World Bank, 2007. Informality: Exit and exclusion, Washington D.C. 